\title{
NGOs perspective over CSR actions in an emerging economy
}

\author{
Dragoș Andrei STOICA \\ The Bucharest University of Economic Studies, Bucharest, Romania \\ dragos.stoica@stud.ase.ro \\ Ioan Radu PETRARIU \\ The Bucharest University of Economic Studies, Bucharest, Romania \\ ioanradupetrariu@gmail.com \\ Raluca-Georgiana CHIVU \\ The Bucharest University of Economic Studies, Bucharest, Romania \\ raluca.chivu0126@gmail.com
}

PICBE | 933

\begin{abstract}
In this paper we investigate the perceptions of non-profit organizations over the CSR activities and their effects in the Romanian society. By conducting a survey for a sample of 105 NGOs from the most important cities in Romania, we aim to highlight the differences between corporate reports and real effects in our society as it pertains to CSR actions conducted by companies. Over the years, in order to attain legitimacy, corporations have become more transparent and involved in social and environmental issues. In the case of Romania, many actions like this are implemented in a partnership consisting of corporations and NGOs, thus the latter becomes a very important actor in achieving sustainability for our society. The responses highlight the disparity between the reported actions and results and real effects in the community.
\end{abstract}

Keywords: CSR, NGO, sustainability, globalisation, private sector.

\section{Introduction}

Corporate Social Responsibility (CSR) has become one of the most important elements in the foundation for understanding and accomplishing the challenges of the global stakeholder (Heath and $\mathrm{Ni}, 2008$ ). In the last decades, activist groups formed to alter every aspect of business and government and what seemed to be a local concern, became a global problem. Through the development of technology we as a society managed to become closer to one and other. The space barrier has mostly been cut. Thus, businesses and governments around the world can receive instant and detailed information in order to make optimal decisions.

The problem of mass production and consumption by corporations became a longing problem for the ending of the 20th Century. Large entities have slowly started to dominate the way in which business and politics are performed, which in turn distorts not only their image in society, but also introduces the concerns for sustainability.

The efficiency of the markets and business practices could in fact harm our society if unchecked. Interest in CSR arose as activists at all points of the ideological and geographical compass called for higher standards for business and government performance. Non-profit organisations (NGOs) asked for reinvestment of a small part of a business's profits and academics debated over the differences between the modern and post-modern organization (Heath and $\mathrm{Ni}, 2008$ ). 
The role of the corporation in society has been feverishly debated in the last half a century (Basu and Palazzo, 2008). Through this process it was revealed how each society uses and implements CSR standards and actions, thus creating a non-uniform platform for discussion. Critics have argued that CSR can become insulated, self-serving, and selfaffirming - often to the detriment of the society where it was supposed to bring social, political, technical, and financial benefits (Heath and $\mathrm{Ni}, 2008$ ).

PICBE | 934

In this context, the role of NGOs becomes very important. Through their experience they become actors that can offer a fair image of the CSR status within organisations.

Taking into account the fact that CSR is as old as organizations themselves, we investigate in this paper, the ways in which entities in the Romanian private sector develop CSR actions and the extent to which they can be effective for a sustainable society. The question thus arises: Do entities, in their quest to achieving their goals, mission and vision, add value to the development of a more sustainable society?

Over the past two decades there has been a great deal of research into the CSR reporting practices within the context of developed nations. However, this is not the case for developing countries. Due to globalization, the research on CSR within the context of developing nations is essential.

The remainder of this paper is organized as follows: Section 1 presents a review of the relevant literature on CSR and NGOs. Section 2 then presents the theoretical framework employed. Section 3 details the research methodology, while Section 4 presents the results analysis. We finally conclude and present the paper's contributions to literature.

\section{Literature review}

\section{The role of CSR in society}

The world is striving to achieve sustainability and efficiency at all levels. Governments, the private sector and the general public are all aiming for a viable and equitable society (Wim Heijman, 2016). It all started with the industrial revolution, which marked a major turning point in history. With effects like rapid technological development and the rise in GDP per capita, the industrial revolution had put in motion the biggest challenge of modern history globalisation.

Three hundred years later, into the present day, a new era in the socio-economic development was ushered. Globalisation has had an important impact over the lifestyles and workings of countries, institutions, business and individuals (Pop and Valeriu, 2015; Lehtonen and Okkonen, 2016). The chase for wealth and power has helped create a multitude of channels and movements that tackle the negative effects of globalisation.

Romania is one of the emerging countries in Central and Eastern Europe (CEE), which after the fall of communism was affected by several waves of reforms in the field of accounting that were based on strong influences from the international sphere (Albu et al., 2011). After the fall of communism in December 1989, Romania went through a prolonged phase of reform that affected political, economic and social policies. Romania's uninterrupted interest in joining the European Union and the desire to show legislative efforts in the European direction have led the national regulatory authority to pursue the implementation of international standards and rules (accounting standards, CSR and corporate governance policies etc.) and to change the way in which companies conduct their reporting (Albu et al., 2014; Ionaşcu et al., 2014). The changes brought about by these innovations have begun to be investigated (Jamali \& Neville, 2011), but national history and context creates a favourable 
and interesting space for research due to continues changes in the economic, political and social environment.

The frequency of the emergence of social and environmental aspects in the reports prepared by the Romanian companies is increasing (Guşe et al., 2016). Entities must focus their work not only on business side, but also on social and environmental aspects. This has led to the publication of an increasing number of reports on CSR activities developed by organizations, the analysis of non-financial information by stakeholders and the development of standards and regulations in the field. We believe it is important to study the context in which non-financial reporting in Romania has developed and the initiatives of the various stakeholders on social and environmental reporting.

The concept of CSR has become more and more popular in the last years. Through debates and discussions, the international community has tried to confer a universal definition to this concept. Given the effects of globalization and national culture, the notion of corporate social responsibility has conjured a variety of images all across the world (Albu et. al, 2011). The foundation of the concept has been established my mainly two parties international organizations and researchers:

- CSR is a concept whereby companies integrate social and environmental concerns into their business operations and in their interaction with their stakeholders on a voluntary basis (European Commission, 2011);

- CSR is "the process by which managers within an organization think about and discuss relationships with stakeholders as well as their roles in relation to the common good, along with their behavioural disposition with respect to the fulfilment and achievement of these roles and relationships" (Heath and $\mathrm{Ni}, 2008$ );

- CSR is "a commitment to improve community well-being through discretionary business practices and contribution of corporate resources" (Kotler and Lee, 2005).

In the 1980s the discussion about CSR was generated by responsibility and morality towards society. The ability "to act with rectitude, to refer their policies and plans to a culture of ethics that embraces the most fundamental moral principles of humankind. The heart of CSR is a firm interdependence between business and society" (Frederick, 1986). This link, between CSR actions and economic performance, has been highlighted, in time, through many studies (Frederick, 1986; Heath and Ni, 2008; Albu et. al, 2011). Thus, CSR activities become more and more important in order for companies to help develop a foundation of reducing cost, gain marketing advantage and attaining sustainability for their communities (Albu et. al, 2011). Also, a key concern in building a strong corporate brand arises when considering the configuration of a company's strategy, culture, and status.

In the context of the implementation of the European Directive 2014/95/EU for nonfinancial reporting, Romania becomes a good starting point for such research. Becoming a member of the European Union (EU) over twelve years ago, the country has not shown its ability to adapt easily to the new requirements associated with its position. The non-financial reporting directive has entered into force in the national regulations since 2016 (OMFP 1938/2016). However, this does not provide any clear directions on how to report. Thus, companies can choose from a multitude of reporting options. Companies can make use of national frameworks, European Union frameworks or other recognized international frameworks. In 2016, only 31 of the over 30,000 CSR reports included in the GRI database were published by companies operating in Romania, and none of them reached the highest level of application - A+ (Guşe et al., 2016). This result offers a limited image of the level of 
experience and success that Romanian companies have had with CSR reporting. Also, previous studies (Albu et al., 2011; Albu et al., 2014) show that these competencies, those related to CSR, are not among those required by an employer from a future accountant.

Albu et al. (2011), divides the benefits regarding CSR implementation into four categories:

- Cost reduction (materials, energy, time etc.);

- Productivity improvement (boosting motivation, low absenteeism, reduced turnover);

- Reducing management risk (easier access to credits, increased value of assets for investors etc.);

- Improving the image of the company in society.

In order for society to acknowledge improvements in this area, the company has to present CSR related information through its reporting, whether through annual reports, CSR reports, Sustainability reports etc. According to Dumitru et al. (2015), reporting is mostly motivated by the immediate and strategic objectives of the entity. Studying a significant number of reports we can observe that organizations take into account the aspects of sustainability in their activities. Also, the incentives associated with marketing, such as competitive advantage, peer and industry pressures, image management, public relations, corporate reporting awards, financial benefits from investor reactions, play an important role in shaping the content of a company's reports.

A socially responsible company strives to make a profit, obey the law, practice ethics, and behave in a generous manner that benefits society. The scope of CSR can range from a wide view of actions that appear to further some social good, beyond the interests of the firm and that which is required by law, to a narrow one focusing on maximizing shareholder wealth. Thus, it is necessary to view the concept of CSR in a broader image (Lee et al., 2013).

According to Albu et al. (2011), the Romanian environment (consisting of both the private sectors and NGOs) has become more aware of the importance of good CSR practices.

There is little investigation concerning the link between NGOs perception of CSR activities and organizations goals and actions, although some studies refer to an indirect relationship between these two parties (Arenas et al., 2009).

\section{The role of Non-profit organization in society}

A non-governmental organization (NGO) is represented by any non-profit, voluntary group which is organized at the local, national or international level. Task-oriented and driven by people with a common interest, NGOs perform a variety of services and humanitarian actions, like: bringing communities concerns to Governments, advocating for policies and encouraging political and social participation etc. Some NGOs are organized around specific issues, such as human rights, environmental issues or health issues. They provide analysis and expertise, serve as early warning mechanisms and help monitor and implement national international agreements.

NGOs are committed to work in the public interest, whilst also performing accountability for their actions and attaining compliance with national and international norms. Arenas et al. (2009), categorizes NGOs taking into account the type of goods and services that they provide: from goods and services that mainly affect individuals to those affecting the quality of life of entire communities; from goods and services concerned with 
preservation of the natural environment, cultural heritage or health to those that aim to promote social change.

In the past decade, NGOs have emerged in Romania as important actors in the community, and they have sought to engage with public institutions, private corporation and other groups in order to help improve the populations wellbeing and to achieve long-term sustainability. To advance their agenda, NGOs establish different types of relationships with companies: from collaborative to confrontational actions, such as protests, boycotts and civil suits. This represents a strong incentive for companies to engage in relationships with NGOs, since ignoring or disparaging these actions can have unwanted consequences for the entity.

The Global Reporting Initiative, is a multi-stakeholder initiative that encompasses NGOs and businesses. The OECD started consultations with civil society organisations for its Guidelines for Multinational Enterprises in 2000, and the European Multi-stakeholder Forum on CSR (European Commission) also began talks in 2002. NGOs have participated in all these consultations and debates related to the advancement of CSR. However, despite increasing participation in global networks and interest in global issues, NGO influence and relationship with business also depend heavily on national and regional contexts.

In Romania, the NGOs attitude towards the private sector has changed for the better in the last years. Companies view those organisations as necessary partners for developing actions for the improvement of communities. At the same time, expectations regarding businesses' commitment to social development are also growing.

Also, the overall attitude towards the NGOs has also changed. They have become more relevant to society's well-being. In the CSR context, there has been an increasing institutionalisation of NGO activity, many companies including NGOs in their stakeholder dialogue (Arenas et al., 2009).

\section{Theoretical framework}

Following the research of Islam (2017) on the issue of implementing CSR actions to attain sustainability, I focus on the relationship between NGOs and companies from a legitimacy point of view. Through the 90's and 2000's, reporting on those actions has gained more and more traction. During this period a number of theories (i.e. stakeholder theory, political economy theory, legitimacy theory) were employed in order to better describe CSR reporting practices (Owen, 2008).

Legitimacy is a status which occurs when an entities value system is consistent with the value system of the community in which the organisation is a part of. Thus, legitimacy is a framework that companies use to meet the external standards and norms (Deegan, 2003). Legitimacy theory has its foundations in the theoretical paradigm of political economy (Islam, 2017). The paradigm suggests that the economic sphere can't function without the political, social and institutional sphere. Thus, it highlights the power struggles that appear within society and the various problems that transpire between various groups within society (Deegan, 2003). The need for uniformity for presentation and implementation of actions and results thus appears. Governments, international organizations, industry bodies, the accounting profession (i.e. the World Business Council for Sustainable Development, the Global Reporting Initiative, the Institute for Social and Ethical Accountability, the Council on Economic Priorities) have been actively involved in the development of CSR standards.

A widespread view of the legitimacy theory in the context of CSR reporting is presented in Deegan's work. Through his research we has found a number of studies that 
have used this theory in order to explain the motivation behind CSR reporting. The information in the annual reports of companies is used in order to attain legitimacy in society (Deegan, 2003). Legitimacy and the ever-changing social expectations are interconnected. Social expectations change because the society has long searched for the kind of community in which everyone is enabled to have a decent lifestyle, can access justice, equality, a pollution-free environment and a variety of other things, in order to embrace an equitable human existence.

\section{Methodology}

The data was collected using a questionnaire survey that could be completed by NGO representatives from Romania, in March 2018. This group was surveyed because of their vast experience in the implementation of CSR actions in partnership with companies from the Romanian private sector.

Pre-survey contact was made with the surveyed NGOs during the weeks prior to delivery. The questionnaire was tested for readability, completeness and clarity through three pilot tests prior to dispatch and the suggestions offered were included in the final version.

The survey was comprised of 10 questions. From those, three questions were focused on the respondent's background and experience, four were multiple-choice questions regarding the activities and their focus in the CSR area of entities from the Romanian private sector, and three questions were based on the Likert scale (from 1 to 5) highlighting the relationship between CSR actions and CSR reporting.

The sample size of the surveyed population was comprised of the representatives of 105 NGOs. Of these, 58 completed the questionnaire, indicating a response rate of $55.23 \%$. This exceeds the typical response rate in questionnaire surveys (Nazari, Kline, \& Herremans, 2006). The geographical disparity is also relevant in this case. The NGOs span over 17 important cities in Romania. Accordingly, the sample was deemed to be representative of the underlying population.

\section{Results and discussions}

Both the actors' commitment to attaining legitimacy through sustainability is visible from their actions, reports and public opinion. In the current socio-economic state the concept of corporate social responsibility (CSR) has become more vital than ever for companies and individuals. The world economic crisis has created many setbacks that spawn in almost all communities and enterprises need to play an important role in the process of find solutions. There is a rising interest towards sustainability reporting all over the world and in Romania in particular with more and more corporations prepared to provide information about social and environmental actions in the annual reports. This being said, the number of stand-alone CSR reports remains fairly low, at the national level.

Romanian NGOs have been very active and vocal in the past years in regards to women empowerment. This notion is proven by the number of women elected into the NGOs boards of directors. With an average of 6 spots at the management level for an NGO, over $65 \%$ of those chairs are occupied by women.

The survey was sent to a number of $105 \mathrm{NGO}$ representatives, from which a total of 58 have responded $(55.23 \%)$. As we can see from table 1 , the $62.1 \%$ of the respondents are 
female, and $37.9 \%$ are male. From those $48.3 \%$ have are aged between 22 and 25 years, and the remainder (51.7\%) are situated between 18 and 21 years. All of the respondents are students in Universities from all over the country. The majority of the participants experience regarding CSR (58.6\%) is situated between 1 and 3 years, with the remainder (41.4\%) situated under 1 year.

Table 1. Respondents' background and experience

\begin{tabular}{|l|l|l|}
\hline Enquires & Male & Female \\
\hline Respondents age & 13 & 17 \\
\hline Ages between 18 and 21 & 9 & 19 \\
\hline Ages between 22 and 25 & \multicolumn{2}{l|}{} \\
\hline Respondents experience regarding CSR activities & 10 & 14 \\
\hline Experience less than 1 year & 12 & 22 \\
\hline Experience between 1 and 3 years & \multicolumn{2}{l|}{ Source: Authors' own research. }
\end{tabular}

Respondents were asked to make a distinction between the areas in which companies implement more CSR actions and the areas which they highlight in their annual statements. The results are presented below in graphic 1 . As we can see, companies put more emphasis in their annual reports, in regards to their CSR activities, on areas such as: charity work (33), education (41) and employment enhancing and vocational skills (35). At the other side of the spectre, the most visible CSR actions, from the respondents' point of view, in the communities are those pertaining to employment enhancing and vocational skills (39), education (34) and environment (32). Actions in areas such as health and sanitation, rural development and gender equality do not rank very high on the priority list of entities in Romania.

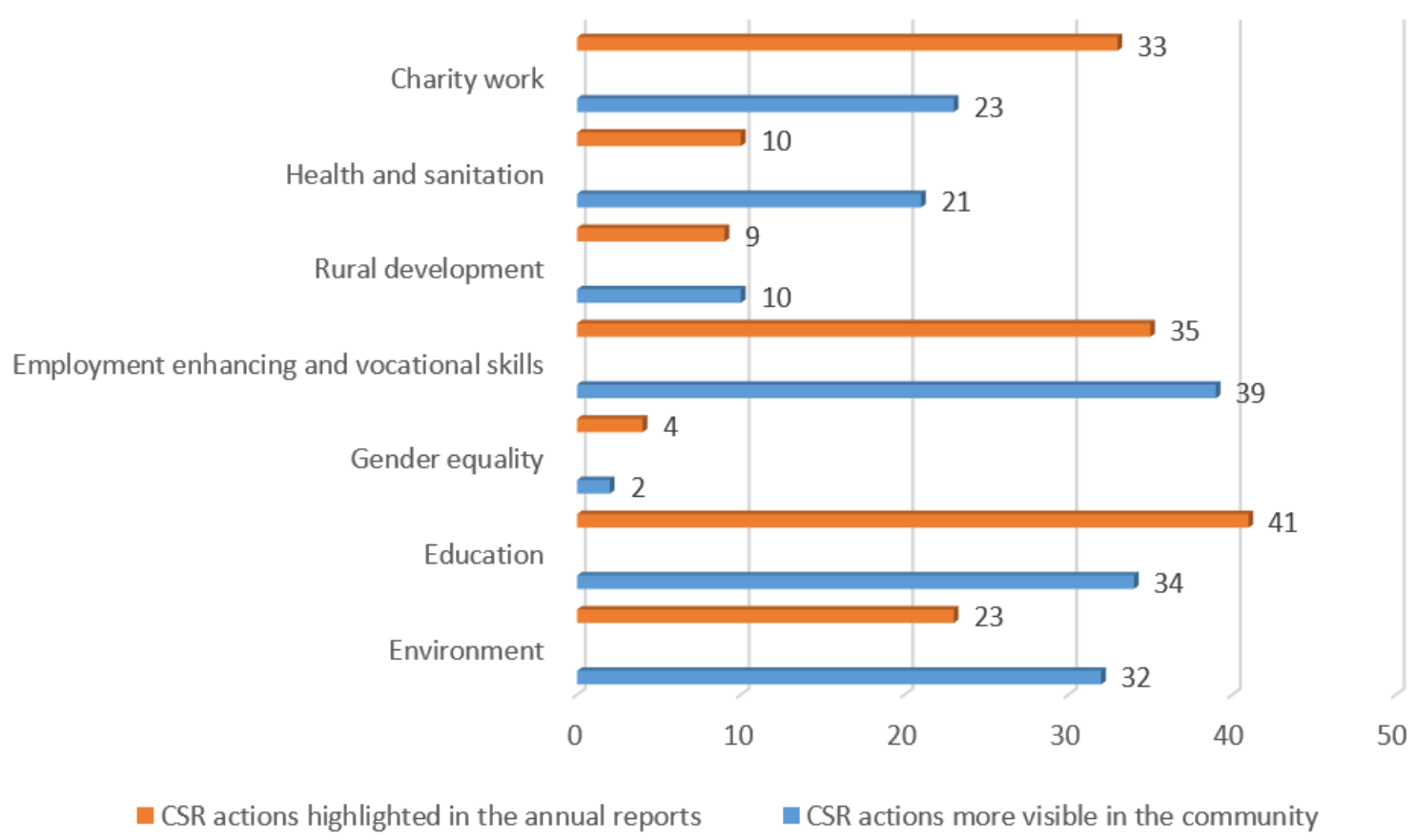

Graphic 1. CSR focus areas vs. reporting areas

Source: Authors' own research. 
Table 2. Objectives for CSR activities and resources employed

\begin{tabular}{|c|c|c|c|c|c|c|c|c|c|c|}
\hline & \multicolumn{2}{|c|}{$\begin{array}{l}\text { It benefits the } \\
\text { environment }\end{array}$} & \multicolumn{2}{|c|}{$\begin{array}{l}\text { It } \\
\text { empowers } \\
\text { individuals }\end{array}$} & \multicolumn{2}{|c|}{$\begin{array}{l}\text { It brings an } \\
\text { improvement } \\
\text { to the } \\
\text { educational } \\
\text { process }\end{array}$} & \multicolumn{2}{|c|}{$\begin{array}{l}\text { Tax } \\
\text { purposes }\end{array}$} & \multicolumn{2}{|c|}{$\begin{array}{l}\text { It helps } \\
\text { improve the } \\
\text { public } \\
\text { perception of } \\
\text { the company }\end{array}$} \\
\hline & $<3$ & $>=3$ & $<3$ & $>=3$ & $<3$ & $>=3$ & $<3$ & $>=3$ & $<3$ & $>=3$ \\
\hline Money & 19 & 4 & 21 & 2 & 4 & 19 & 1 & 34 & 0 & 23 \\
\hline $\begin{array}{l}\text { Speakers and } \\
\text { trainers }\end{array}$ & 28 & 6 & 26 & 8 & 2 & 32 & 1 & 22 & 0 & 34 \\
\hline Infrastructure & 28 & 3 & 29 & 2 & 3 & 28 & 0 & 31 & 0 & 31 \\
\hline Products & 24 & 4 & 22 & 6 & 4 & 24 & 1 & 27 & 0 & 28 \\
\hline $\begin{array}{l}\text { Internship } \\
\text { positions for } \\
\text { students }\end{array}$ & 28 & 6 & 25 & 9 & 2 & 32 & 0 & 33 & 0 & 34 \\
\hline
\end{tabular}

Source: Authors' own research.

Participants to the survey were asked to assess on Likert scale (where 1 is the lowest and 5 the highest), based on their personal experience, the motivation for companies to engage into CSR activities, and also to highlight, through a multiple choice question, the main resources the entities invest into those actions in order for them to succeed. I have correlated those two questions into table 2 by choosing as positive markers ratings starting over or equal with 3 points.

Companies put less emphasis on environmental concerns, but when they develop CSR projects in this area the main resources used in accomplishing their goals are related to brining in speakers and trainers to empower and prepare the youth in environmental problems (28); infrastructure, they open spaces for participants do develop environmental actions (28); and offering internship position for the youth in departments that have a core activity related to environmental issues (28).

Another low priority for companies is represented by the empowerment of individuals. Through those activities the main commitments rely in the areas pertaining to infrastructure (29), speakers and trainers (26) and internship position for students (25).

At the other end of the spectre we can find objectives for CSR activities like: the improvement of the educational process (which heavily relies on speakers and trainers -32 - infrastructure - 28 - and internships - 32 -), tax purposes (in this case we see the emphasis on resources like money - 34 - and internship positions - 32 -) and the improvement of the public's perception of the company (speakers and trainers - 34 - infrastructure - 31 - and internships - $34-$ ).

From those indicators we can observe the reluctance of companies to allocate special resources for the completion of CSR actions (i.e. money or products), instead they tend to use existing resources by reallocating them for specific CSR projects. 
Table 3. The importance of sustainability in organisations

\begin{tabular}{|c|c|c|c|c|}
\hline & $\begin{array}{l}\text { Min. } \\
\text { value }\end{array}$ & $\begin{array}{l}\text { Max. } \\
\text { value }\end{array}$ & Average & Median \\
\hline $\begin{array}{l}\text { Through their actions companies understand the importance of } \\
\text { sustainability }\end{array}$ & 2 & 4 & 3.48 & 4 \\
\hline Companies invest resources to develop sustainability programs & 2 & 5 & 3.48 & 3 \\
\hline $\begin{array}{l}\text { Companies have a department or specialized employees to } \\
\text { tackle with sustainability issues and disclosures }\end{array}$ & 1 & 4 & 1.41 & 1 \\
\hline Companies invest resources to attain proper disclosure & 1 & 4 & 3.05 & 3 \\
\hline
\end{tabular}

Participants made the assessments for the next enquires using the Likert scale (where 1 is the lowest and 5 the highest). Through the information presented above in table 3 , we can see that companies from the Romanian private sector acknowledge the importance of sustainability and the need to invest resources in both the creation and the disclosure of CSR projects/activities. A problem that many developing countries face is the low priority in developing a specialized department or division to tackle with problems of CSR and sustainability. Most of the companies rely on the human resources department to take on most of those responsibilities.

Table 4, presents the overall vision of companies in regards to the creation and implementation of CSR activities. There is a strong sense that those actions will in turn bring a monetary return to the company (attracting/retaining clients, maintaining a healthy relationship with investors and developing their employee pool). An interesting result is represented by the support offered to NGOs for the development of CSR actions. In Romania, NGOs usually have a good relationship with enterprises and often act as "contractors for CSR activities" on behalf of the company.

The awareness in regards to sustainability and the openness to non-corporate partnerships creates a healthy environment and sets the premises of a long-term strategy for attaining sustainability.

Table 4. Organisations vision over CSR activities

\begin{tabular}{|l|l|l|l|l|}
\hline & $\begin{array}{l}\text { Min. } \\
\text { value }\end{array}$ & $\begin{array}{l}\text { Max. } \\
\text { value }\end{array}$ & Average & Median \\
\hline $\begin{array}{l}\text { The concept as a voluntary action that integrates social and } \\
\text { environmental concerns }\end{array}$ & 1 & 4 & 2.91 & 3 \\
\hline The concept as a mean to promote the organization & 2 & 5 & 3.16 & 3 \\
\hline $\begin{array}{l}\text { The concept as a way to attract new clients and/or retain old } \\
\text { ones }\end{array}$ & 2 & 5 & 3.66 & 4 \\
\hline The concept as a way to support NGOs & 2 & 5 & 3.73 & 4 \\
\hline $\begin{array}{l}\text { The concept as a way to create and maintain relationship } \\
\text { with stakeholders }\end{array}$ & 2 & 4 & 3.12 & 3 \\
\hline The concept as a way to attract and retain employees & 2 & 4 & 3.08 & 3 \\
\hline
\end{tabular}

Table 5, reaffirms the findings presented in this paper. We can observe that all the indicators scores are above average, with a median of 3 . The two most important factors that were identified and strengthened are the positive impacts that the overall CSR activity brings to communities all across the country (3.25) and also the fair presentation of CSR information in the annual statements (3.39). 
To be fair, we need to point out the fact, that even though some information is presented in the statements (for the CSR activity) there is no comprehensive description and many of the companies release some information in order to bring in gains. Moreover, there are only a handful of companies (mostly listed companies) that present separate reports for CSR. From this perspective, we can safely state that we have a long way to go in order to obtain true and relevant CSR and sustainability information.

Table 5. Overview of the company's vision and impact regarding CSR

\begin{tabular}{|l|l|l|l|l|}
\hline & $\begin{array}{l}\text { Min. } \\
\text { value }\end{array}$ & $\begin{array}{l}\text { Max. } \\
\text { value }\end{array}$ & Average & Median \\
\hline $\begin{array}{l}\text { Companies are open to the idea of entering into a partnership } \\
\text { with NGOs }\end{array}$ & 2 & 5 & 3.28 & 3 \\
\hline $\begin{array}{l}\text { Companies are bringing in real and impactful benefits to } \\
\text { communities }\end{array}$ & 1 & 5 & 3.25 & 3 \\
\hline $\begin{array}{l}\text { The statements published in the annual reports give a fair and } \\
\text { true image of the actions that they develop }\end{array}$ & 2 & 5 & 3.39 & 3 \\
\hline $\begin{array}{l}\text { CSR actions implemented by companies in the private sector } \\
\text { have a significant impact on individuals and/or the } \\
\text { environment }\end{array}$ & 1 & 5 & 3.05 & 3 \\
\hline $\begin{array}{l}\text { Companies disclose in their annual reports a sufficient amount } \\
\text { of information regarding their CSR activity }\end{array}$ & 2 & 5 & 3.08 & 3 \\
\hline $\begin{array}{l}\text { CSR actions implemented by companies address important } \\
\text { needs of the community }\end{array}$ & 2 & 5 & 3.51 & 3 \\
\hline $\begin{array}{l}\text { Listed companies tend to present more information regarding } \\
\text { CSR activity than non-listed companies }\end{array}$ & 1 & 5 & 3.08 & 3 \\
\hline
\end{tabular}

Source: Authors' own research.

Fundamentally, NGO representatives can and must continue to bring the discussion regarding CSR into the public attention as a mean to help shape the mission/vision, performance standards, and philosophy or culture of companies. They must engage with other actors in order to discover, consider, evaluate, and implement facts and opinions that individually and collectively advance the common good. Finally, CSR activities must not only help develop and define the culture of an organisation internally, but, also externally, for the whole of society.

\section{Conclusion}

The purpose of the study was to investigate the perceptions of non-profit organizations over the CSR activities and their effects in the Romanian society. We have also highlighted the differences between corporate reports and the real effects of CSR actions conducted by companies.

This study contributes to the current literature by shining a light over the way in which companies develop CSR activities in the Romanian private sector. For a developing country, non-profits are an important voice through which the community can keep in check governments, corporations and other groups of actors. Thus, in order to attain legitimacy in a society, enterprises will engage with non-profits into discussions and projects in order to evolve. Also, in order for a society to acknowledge improvements in this area, the entity must present more information related to its CSR activity.

The study bases its findings on the opinion of the Romanian youth who achieved the feat of managing a relevant and important NGO at the local or at the national level. From this 
analysis we can conclude that CSR activities initiated, developed or supported by companies are on the rise and more and more connections are being made between actors in order to obtain long-term sustainability. This being said we can see the reluctance of companies to allocate special resources for the completion of CSR actions (i.e. money or products), instead they tend to use existing resources by reallocating them for specific CSR projects. Also, many enterprises that engage in CSR activities present some relevant information pertaining those actions, but still, this seems to have become a more complex problem due to the fact that the data presented is often insufficient for third parties to make decisions or to voice strong opinions.

This paper can help bring those issues into attention, and can be a starting point for a more in-depth analysis. Future development of CSR initiatives in Romania is needed, both from a legislative point of view and from a reporting standpoint. Through the use interviews with NGO representatives, company representatives and members of the political spectre, we can obtain a more complete image of the CSR sphere in the case of a developing country.

\section{References}

Albu, C.N., Albu, N., \& Alexander, D. (2014). When global accounting standards meet the local context. Insights from an emerging economy. Critical Perspectives on Accounting, 25(6), 489-510.

Albu, C.N., Albu, N., Fekete, S., Garbina, M.M., Strouhal, J., \& Mullerova, L. (2011). An analysis of the IFRS for SMEs implementation in the Czech Republic, Hungary, Romania and Turkey. Journal of International Financial Management \& Accounting, 24(2), 140-175.

Arenas, D., Lozano, J.M., \& Albareda, L. (2009). The Role of NGOs in CSR: Mutual Perceptions among Stakeholders. Journal of Business Ethics, 88(1), 175-197.

Basu, K., \& Palazzo, G. (2008). Corporate social responsibility: A process model of sensemaking. Academy of Management Review, 33(1), 122-136.

Deegan, C. (2002). The Legitimizing effect of Social and Environmental Disclosures: A Theoretical Foundation. Accounting, Auditing \& Accountability Journal, 15(3), 282311.

Dumitru, M., Guse, R.G., Feleaga, L., Mangiuc, D.M., \& Feldioreanu, A.I. (2015). Marketing Communications of Value Creation in Sustainable Organizations. The Practice of Integrated Reports. Amfiteatru Economic, 17(40), 955-976.

European Commission, (2012). A renewed EU strategy 2011-14 for Corporate Social Responsibility.

Frederick, W.C. (1986). Toward CSR3: Why ethical analysis is indispensable and unavoidable in corporate affairs. California Management Review, 28(4), 126-141.

Gușe, R.G., Almășan, A., Circa, C., \& Dumitru, M. (2016). The role of the stakeholders in the institutionalization of the CSR reporting in Romania. Accounting and Management Information Systems, 15(2), 304-340.

Heath, R.L., \& Ni, L. (2008). The challenge of Corporate Responsibility. Institute for Public Relations.

Heijman, W. (2016). How big is the bio-business? Notes on measuring the size of the Dutch bio-economy. NJAS - Wageningen Journal of Life Sciences, 77(1), 5-8.

Ionaşcu, M., Ionaşcu, I., Săcărin, M., \& Minu, M. (2014). IFRS adoption in developing countries: the case of Romania. Accounting and Management Information Systems, 13(2), 311-350. 
Islam, M.A. (2017). CSR Reporting and Legitimacy Theory: Some Thoughts on Future Research Agenda. The Dynamics of Corporate Social Responsibility: A Critical Approach to Theory and Practice.

Jamali, D., \& Neville, B. (2011). Convergence Versus Divergence of CSR in Developing Countries: An Embedded Multi-Layered Institutional Lens. Journal of Business Ethics, 102, 599-621.

Kotler, R., \& Lee, N. (2005). Corporate social responsibility. Hoboken, New Jersey: John Wiley $\&$ Sons.

Lee, E.M., Park, S.Y., \& Lee, H.J. (2013). Employee perception of CSR activities: Its antecedents and consequences. Journal of Business Research, 66(10), 1716-1724.

Lehtonen, O., \& Okkonen, L. (2016). Socio-economic impacts of community wind power projects in Northern Scotland. Renewable Energy, Elsevier, 85(3), 826-833.

Nazari, K., \& Herremans, (2006). Conducting survey research in management accounting. Methodological Issues in Accounting Research: Theories, Methods and Issues. Spiramus, London.

Owen, D. (2008). Chronicles of Wasted Time? A Personal Reflection on the Current State of, and Future Prospects for, Social and Environmental Accounting Research. Accounting, Auditing \& Accountability Journal, 21(2), 240-67.

Pop, N., \& Valeriu, I.F. (2015). Crisis, Globalisation, Global Currency. Procedia Economics and Finance, 22(1), 479-484. 